\title{
Evaluation of Biorational Pesticides for Management of Shoot and Fruit Borer (Leucinodes orbonalis G.) in Brinjal
}

\author{
S. Gayathri ${ }^{1}$, B. Geetha ${ }^{2^{*}}$, T. Abdul Razak ${ }^{1}$ and M.I. Manivannan ${ }^{3}$ \\ ${ }^{1}$ Department of Agricultural Entomology, AC \& RI, Killikulam, Thoothakudi - 625282, India \\ ${ }^{2}$ Tapioca and Castor Research Station, Yethapur, Salem, India \\ ${ }^{3}$ Horticultural Research Institute, Kodaikanal, India \\ *Corresponding author
}

\begin{tabular}{|c|c|}
\hline & A B S T R A C T \\
\hline $\begin{array}{l}\text { Biorational } \\
\text { pesticides, Brinjal } \\
\text { shoot and fruit } \\
\text { borer, Damage, } \\
\text { Yield }\end{array}$ & \multirow{3}{*}{$\begin{array}{l}\text { Shoot and fruit borer (Leucinodes orbonalis G.) is one of the most destructive pests in } \\
\text { brinjal in South Asia. Studies on effectiveness of different chemical insecticides against } \\
\text { shoot and fruit borer causes } 20-60 \% \text { yield reduction was evaluated under field condition } \\
\text { at Agricultural College and Research Institute, Killikulam, Thoothakudi during kharif from } \\
\text { July } 2018 \text { to October } 2018 \text {. Shoot and fruit infestation were minimum in Spinosad } 45 \mathrm{SC} \\
\text { treated plots with the per cent of } 9.94 \text { in shoots and } 11.71 \text { in fruits when compared to the } \\
\text { untreated check }(30.99 \%) \text {. Next to this, Emamectin benzoate } 5 \mathrm{WG} \text { and Novaluron } 10 \mathrm{EC} \\
\text { performed better with the shoot and fruit infestation viz., } 11.34 \% \text { to } 12.70 \% \text { in shoot and } \\
13.05 \% \text { to } 14.30 \% \text { in fruits respectively. The average yield recorded was ranging from } \\
20.97 \mathrm{t} / \mathrm{ha} \text { to } 13.40 \mathrm{t} / \mathrm{ha} \text { in pesticide treated plots when compared to the untreated check } \\
(8.52 \mathrm{t} / \mathrm{ha} \text { ). The highest yield of } 20.97 \mathrm{t} / \mathrm{ha} \text { was recorded in Spinosad } 45 \mathrm{SC} \text { treated plots } \\
\text { followed by Emamaectin benzoate5 WG }(18.24 \mathrm{t} / \mathrm{ha} \text { and Novaluron } 10 \mathrm{EC}(17.90 \mathrm{t} / \mathrm{ha} \text { ). }\end{array}$} \\
\hline Article Info & \\
\hline $\begin{array}{l}\text { Accepted: } \\
\text { 24 May } 2019 \\
\text { Available Online: } \\
\text { 10 June } 2019\end{array}$ & \\
\hline
\end{tabular}

\section{Introduction}

Brinjal (Solanum melongena L.) also known as egg plant is one of the most economically important vegetable crops in South Asia. It referred as "King of Vegetables" belongs to the Solanaceae family. It contain rich source of minerals (Calcium, magnesium, phosphorus, sodium, potassium, chlorine, iron and vitamins) and also has some medicinal importance (Singh et al., 1963, Jayed et al., 2017). India is the second largest producer of brinjal next to china and it contributes to 94 percent of the country's total vegetable production. It is injured by 26 species of insect pests from nursery to harvest (Choudhary et al., 1977, Regupathy et al., 1997). Biotic and abiotic factors affect the plant growth and productivity of brinjal. Among them one of the most important factors is the damage inflicted by the insect pests and their role in yield reduction. Among the insect pests brinjal shoot and fruit borer infestation causes damage up to 20 to 80 per cent to the whole cropping period (Srinivasa, 2004; Chakraborti and Sarkar, 2011). Predictable insecticides have been recommended for the management of shoot 
and fruit borer in brinjal. Some of the insecticides have shown resistance to these pests besides causing environmental pollution. Conventional pesticides in high doses are continuously used by the farmers for the management of the shoot and fruit borer in brinjal. Unsystematic use of these insecticides developed the resistance, resurgence and environmental hazards with high toxic residue in the brinjal. In this situation, effective alternative technique is required. Biorational pesticides which are required only in small quantities as compared to the conventional insecticides are the best alternate for pest management. Hence the present experiment was conducted to study the efficacy of different bioratioanl pesticides against the shoot and fruit borer in brinjal.

\section{Materials and Methods}

The field experiment was conducted at Agricultural College and Research Institute, Killikulam during kharif 2018. Geographically, the location of the study site is located in $8^{\circ} 46 \mathrm{~N}$ and $77^{\circ} 42 \mathrm{E}$ longitude and at an altitude of $40 \mathrm{~m}$ above MSL in the state of Tamil Nadu. The brinjal variety KKM 1 was used for the field experiment and the thirty days old seedling was transplanted with a spacing of $60 \times 60 \mathrm{~cm}$. Field trial was laid out in randomized Block Design with three replications to evaluate the efficacy of biorational pesticides against shoot and fruit borer in brinjal. The field experiment consists of the treatments viz. $\mathrm{T}_{1}-$ spinosad 45 SC @ 0.5ml/lit, T $2^{-}$Avermectin 18 EC @ 0.4g/lit, $\mathrm{T}_{3^{-}}$Buprofesin $25 \mathrm{SC} @ 0.8 \mathrm{ml} / \mathrm{lit}, \mathrm{T}_{4^{-}}$ Novaluron @ 0.5ml/lit, $\mathrm{T}_{5^{-}}$Emamectin benzoate 5 WG @0.4g/lit, T6- Chlorpyriphos 20 EC @ 2.5ml/lit, T $7^{-}$Untreated control. Treatment spray was imposed at when $5 \%$ ETL of shoot infestation was observed in experimental field. A total of two rounds of foliar sprays were given at 15 days interval. Before spraying shoot and fruit infestation caused by Leucinodes orbonalis was recorded on each plot on 1 day before spraying and post treatment count at $7^{\text {th }}$ and $14^{\text {th }}$ days after each spray. After imposing treatment, the shoot infestation was recorded by counting the number of infested shoots and total healthy shoots from ten randomly selected plants. In each plot the yield was also recorded as the total number of fruits and infested fruits were recorded on number basis in each picking, infested fruits and total number of available fruits were recorded on number basis.. The data were subjected to statistical analysis by analysis of variance and the least significance difference was determined at $5 \%$ probability level.

\section{Shoot infestation}

Number of shoot infested per plant Shoot damage $(\%)=$

Total number of shoots per plant

\section{Fruit infestation}

Number of damaged fruits per plant

Fruit damage $(\%)=$--------------- x 100

Total number of fruits per plant

\section{Results and Discussion}

\section{Effect of biorational insecticides on shoot infestation}

The result on the effect of biorational insecticidal treatments on the Leucinodes orbonalis G. was presented in Table 1. In first spray the minimum shoot infestation was found in Spinosad $45 \mathrm{SC}$ treated plots which was $11.13 \%$ in 14 DAS. The treatment Emamectin benzoate $5 \mathrm{WG}$ showed less percentage of shoot infestation (12.47 at 14 DAS) and Novaluron 10 EC with the reduction of shoot infestation of $14.03 \%$ at 14 DAS. Buprofesin 25 SC was less effective treatment which showed higher shoot 
infestation of $16.11 \%$ at 14 DAS when compared to other treatments.

In second spray also Spinosad 45 SC showed the best reduction of shoot infestation of 6.10 $\%$ at 14 DAS. Next to this, Emamectin benzoate $5 \mathrm{WG}$ treated plots with the reduction of $7.40 \%$ shoot infestation and Novaluron 10 EC reduced the shoot infestation with the percentage of (8.05) at 14 DAS when compared to the untreated check $(33.30 \%)$. In the shoot infestation was minimum in spinosad 45 SC $(9.94 \%)$ followed by Emamectin benzoate $5 \mathrm{WG}$ $(11.34 \%)$ and Novaluron 10 EC (12.70\%).

\section{Effect of insecticides on fruit infestation}

The data on fruit infestation is presented in Table 2. Fruit infestation was declined by the application of Spinosad 45 SC with the per cent fruit infestation of 12.38 in first spray and 7.14 in second spray at 14 DAS when compared to the count taken from before spray $(26.35 \%)$. The treatment Emamectin benzoate $5 \mathrm{WG}$ was also effective against the shoot and fruit borer and the fruit infestation was ranging from (13.07\% in first spray and $8.36 \%$ in other spray at 14 DAS). It was followed by Novaluron 10 EC with the reduction of fruit infestation $(13.93 \%$ to $10.85 \%$ ) at 14 DAS in first and second spray. Buprofesin 25 EC was less effective against shoot and fruit borer with the reduction of fruit infestation of $14.60 \%$ at 14 DAS in second spray when compared to untreated check (45.79\%). The average yield was ranging from $20.97 \mathrm{t} / \mathrm{ha}$ to $13.40 \mathrm{t} / \mathrm{ha}$ when compared to the untreated check (8.52 t/ha). Among the biorational pesticides the highest yield was recorded in Spinosad 45 SC (20.97 t/ha), Emamectin benzoate 5 WG (18.24 t/ha) and Novaluron 10 EC (17.90 t/ha) treated plots (Fig. 1).

Table.1 Efficacy of biorational insecticides in shoot infestation by Leucinodes orbonalis $\mathrm{G}$

\begin{tabular}{|c|c|c|c|c|c|c|c|c|}
\hline \multirow[t]{2}{*}{ Treatment } & \multicolumn{4}{|c|}{ Shoot infestation (\%) ( $1^{\text {st }}$ spray $)$} & \multicolumn{3}{|c|}{ Shoot infestation (\%) $\left(2^{\text {nd }}\right.$ spray } & \multirow{2}{*}{$\begin{array}{l}\text { Overall } \\
\text { Shoot } \\
\text { Infestation } \\
(\%)\end{array}$} \\
\hline & $\begin{array}{l}\text { Pre treatment } \\
\text { Count }\end{array}$ & 7 DAS & 14 DAS & Mean & 7 DAS & 14 DAS & Mean & \\
\hline T1- Spinosad 45 SC & $\begin{array}{l}21.70 \\
(31.80)\end{array}$ & $\begin{array}{l}14.13 \\
(28.03)^{a}\end{array}$ & $\begin{array}{l}11.13 \\
(26.20)^{\mathrm{a}}\end{array}$ & 12.63 & $\begin{array}{l}8.40 \\
(25.70)^{\mathrm{a}}\end{array}$ & $\begin{array}{l}6.10 \\
(26.20)^{\mathrm{a}}\end{array}$ & 7.25 & 9.94 \\
\hline T2 -Avermectin 18 EC & $\begin{array}{l}20.27 \\
(31.15)\end{array}$ & $\begin{array}{l}19.47 \\
(30.78)^{d}\end{array}$ & $\begin{array}{l}16.37 \\
(29.24)^{c}\end{array}$ & 17.92 & $\begin{array}{l}12.83 \\
(28.42)^{d}\end{array}$ & $\begin{array}{l}9.32 \\
(29.24)^{c}\end{array}$ & 11.08 & 14.50 \\
\hline T3- Buprofesin $25 \mathrm{SC}$ & $\begin{array}{l}22.77 \\
(32.26)\end{array}$ & $\begin{array}{l}21.23 \\
(31.59)^{e}\end{array}$ & $\begin{array}{l}20.70 \\
(31.35)^{e}\end{array}$ & 20.97 & $\begin{array}{l}13.83 \\
(29.99)^{\mathrm{f}}\end{array}$ & $\begin{array}{l}11.79 \\
(31.35)^{\mathrm{e}}\end{array}$ & 12.78 & 16.87 \\
\hline T4 -Novaluron & $\begin{array}{l}21.07 \\
(31.51)\end{array}$ & $\begin{array}{l}18.27 \\
(30.20)^{c}\end{array}$ & $\begin{array}{l}14.03 \\
(27.97)^{b}\end{array}$ & 16.15 & $\begin{array}{l}10.43 \\
(27.03)^{c}\end{array}$ & $\begin{array}{l}8.05 \\
(27.97)^{b}\end{array}$ & 9.24 & 12.70 \\
\hline $\begin{array}{l}\text { T5 -Emamectin } \\
\text { benzoate } 5 \text { WG }\end{array}$ & $\begin{array}{l}20.33 \\
(31.18)\end{array}$ & $\begin{array}{l}16.00 \\
(29.05)^{b}\end{array}$ & $\begin{array}{l}12.47 \\
(27.05)^{b}\end{array}$ & 14.24 & $\begin{array}{l}9.47 \\
(26.42)^{b}\end{array}$ & $\begin{array}{l}7.40 \\
(27.05)^{b}\end{array}$ & 8.44 & 11.34 \\
\hline $\begin{array}{l}\text { T6- Chlorpyriphos } 20 \\
\text { EC }\end{array}$ & $\begin{array}{l}21.97 \\
(31.91)\end{array}$ & $\begin{array}{l}22.57 \\
(32.18)^{d}\end{array}$ & $\begin{array}{l}18.87 \\
(30.49)^{d}\end{array}$ & 20.72 & $\begin{array}{l}13.20 \\
(28.87)^{\mathrm{e}}\end{array}$ & $\begin{array}{l}10.87 \\
(30.49)^{d}\end{array}$ & 12.04 & 16.38 \\
\hline T7- Untreated Check & $\begin{array}{l}23.33 \\
(32.51)\end{array}$ & $\begin{array}{l}25.73 \\
(33.51)^{f}\end{array}$ & $\begin{array}{l}33.30 \\
(36.42)^{f}\end{array}$ & 29.52 & $\begin{array}{l}31.63 \\
(35.80)^{g}\end{array}$ & $\begin{array}{l}33.30 \\
(36.42)^{f}\end{array}$ & 32.47 & 30.99 \\
\hline S Ed & 1.51 & 0.41 & 0.38 & - & 0.46 & 0.39 & - & - \\
\hline $\mathrm{CD}(\mathbf{0 . 0 5})$ & NS & 0.90 & 0.83 & - & 0.99 & 0.85 & - & - \\
\hline
\end{tabular}

Mean of 3 replications

DAS - Days after spray

Figures in parentheses are arcsine transformations

In a column/row mean followed by a common letter are not significantly different at $5 \%$ level by DMRT 
Table.2 Efficacy of biorational insecticides in fruit infestation Leucinodes orbonalis $\mathrm{G}$

\begin{tabular}{|c|c|c|c|c|c|c|c|c|c|}
\hline \multirow[t]{2}{*}{ Treatment } & \multicolumn{4}{|c|}{ Fruit infestation (\%) (1 $1^{\text {st }}$ spray $)$} & \multicolumn{3}{|c|}{$\begin{array}{l}\text { Fruit infestation }(\%)\left(2^{\text {nd }}\right. \\
\text { spray) }\end{array}$} & \multirow{2}{*}{$\begin{array}{l}\text { Overall } \\
\text { Fruit } \\
\text { infestation } \\
(\%)\end{array}$} & \multirow{2}{*}{$\begin{array}{l}\text { Yield } \\
\text { t/ha }\end{array}$} \\
\hline & $\begin{array}{l}\text { Pre } \\
\text { treatment } \\
\text { count }\end{array}$ & 7 DAS & 14 DAS & Mean & 7 DAS & 14 DAS & Mean & & \\
\hline $\begin{array}{l}\text { T1 - Spinosad } 45 \\
\text { SC }\end{array}$ & $\begin{array}{l}26.35 \\
(24.62)\end{array}$ & $\begin{array}{l}19.09 \\
(30.60)^{\mathrm{a}}\end{array}$ & $\begin{array}{l}12.38 \\
(26.99)^{\mathrm{a}}\end{array}$ & 15.74 & $\begin{array}{l}8.21 \\
(24.08)^{\mathrm{a}}\end{array}$ & $\begin{array}{l}7.14 \\
(23.18)^{\mathrm{a}}\end{array}$ & 7.68 & 11.71 & $20.97^{\mathrm{a}}$ \\
\hline $\begin{array}{l}\text { T2 - Avermectin } \\
18 \text { EC }\end{array}$ & $\begin{array}{l}27.32 \\
(25.34)\end{array}$ & $\begin{array}{l}22.90 \\
(32.32)^{d}\end{array}$ & $\begin{array}{l}14.16 \\
(28.04)^{d}\end{array}$ & 18.53 & $\begin{array}{l}12.01 \\
(26.76)^{d}\end{array}$ & $\begin{array}{l}11.30 \\
(26.31)^{\mathrm{c}}\end{array}$ & 11.66 & 15.09 & $16.58^{d}$ \\
\hline $\begin{array}{l}\text { T3 - Buprofesin } \\
25 \text { SC }\end{array}$ & $\begin{array}{l}24.51 \\
(25.48)\end{array}$ & $\begin{array}{l}23.96 \\
(32.78)^{f}\end{array}$ & $\begin{array}{l}16.44 \\
(29.28)^{\mathrm{f}}\end{array}$ & 20.20 & $\begin{array}{l}15.97 \\
(29.03)^{\mathrm{e}}\end{array}$ & $\begin{array}{l}14.60 \\
(28.29)^{d}\end{array}$ & 15.29 & 17.74 & $13.40^{\mathrm{f}}$ \\
\hline T4 - Novaluron & $\begin{array}{l}25.26 \\
(25.30)\end{array}$ & $\begin{array}{l}21.17 \\
(31.56)^{\mathrm{c}}\end{array}$ & $\begin{array}{l}13.93 \\
(27.91)^{\mathrm{c}}\end{array}$ & 17.55 & $\begin{array}{l}11.25 \\
(26.28)^{\mathrm{c}}\end{array}$ & $\begin{array}{l}10.85 \\
(26.01)^{b}\end{array}$ & 11.05 & 14.30 & $17.24^{\mathrm{c}}$ \\
\hline $\begin{array}{l}\text { T5 - Emamectin } \\
\text { benzoate } 5 \text { WG }\end{array}$ & $\begin{array}{l}24.73 \\
(26.23)\end{array}$ & $\begin{array}{l}20.27 \\
(31.15)^{b}\end{array}$ & $\begin{array}{l}13.07 \\
(27.41)^{\mathrm{b}}\end{array}$ & 16.67 & $\begin{array}{l}10.50 \\
(25.77)^{b}\end{array}$ & $\begin{array}{l}8.36 \\
(24.20)^{b}\end{array}$ & 9.43 & 13.05 & $17.90^{b}$ \\
\hline $\begin{array}{l}\text { T6 - } \\
\text { Chlorpyriphos } 20 \\
\text { EC }\end{array}$ & $\begin{array}{l}27.23 \\
(26.01)\end{array}$ & $\begin{array}{l}23.18 \\
(32.44)^{\mathrm{e}}\end{array}$ & $\begin{array}{l}15.47 \\
(28.77)^{\mathrm{e}}\end{array}$ & 19.33 & $\begin{array}{c}13.36 \\
(27.58)^{\mathrm{de}}\end{array}$ & $\begin{array}{l}12.15 \\
(26.85)^{d}\end{array}$ & 12.76 & 16.04 & $15.20^{\mathrm{e}}$ \\
\hline $\begin{array}{l}\text { T7 - Untreated } \\
\text { Check }\end{array}$ & $\begin{array}{l}27.80 \\
(26.42)\end{array}$ & $\begin{array}{l}30.95 \\
(35.55)^{\mathrm{g}}\end{array}$ & $\begin{array}{l}34.07 \\
(36.70)^{\mathrm{g}}\end{array}$ & 32.51 & $\begin{array}{l}40.84 \\
(39.07)^{\mathrm{f}}\end{array}$ & $\begin{array}{l}45.79 \\
(40.73)^{\mathrm{e}}\end{array}$ & 43.30 & 37.91 & $8.52^{\mathrm{g}}$ \\
\hline S Ed & 0.57 & 0.35 & 0.47 & & 0.35 & 0.47 & & - & - \\
\hline CD (0.05) & NS & 0.77 & 1.03 & & 0.77 & 1.02 & & - & - \\
\hline
\end{tabular}

Mean of 3 replications

DAS - Days after spray

Figures in parentheses are arcsine transformations

In a column/row mean followed by a common letter are not significantly different at $5 \%$ level by DMRT

Fig.1 Effect of different biorational insecticides on damage of shoot and fruit infestation

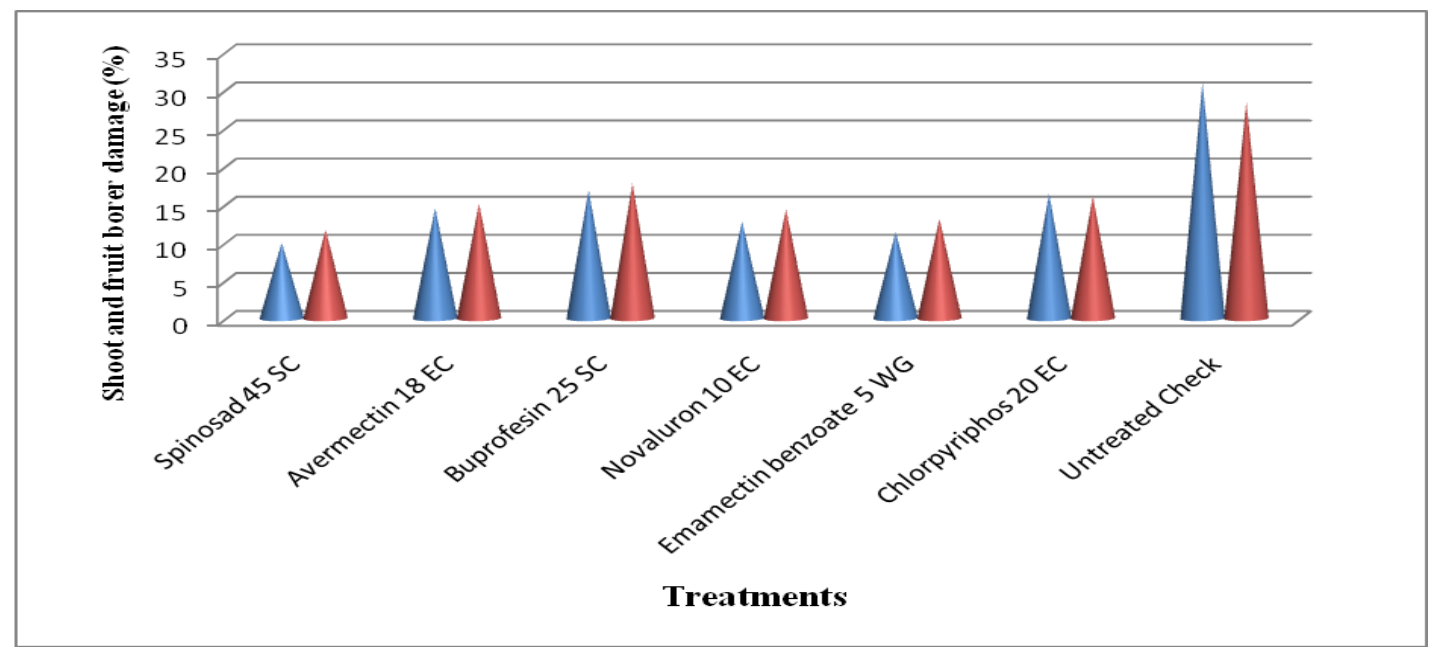

The present findings are in agreement with these results of many researchers. The present findings are in conformity with those of Sinha and Sharma (2008), Mamun (2014) who reported the effectiveness of Spinosad against brinjal shoot and fruit borer. Kalawate et al., 
(2006) and Sharma et al., (2010) reported the efficacy of Spinosad and Emamectin benzoate against shoot and fruit borer which were most effective in comparing to other treatments. Another finding on Emamectin benzoate as effective on brinjal shoot and fruit borer was recorded by Kumar and Devappa (2006). The result on effectivenness of Novaluron for brinjal shoot and fruit borer was similar to the present study in accordance with the reports of Chatterjee and Roy (2004).

Hence this study showed that the biorational insecticides reduced the shoot and fruit infestation in brinjal. Among the biorational pesticides, Spinosad $45 \mathrm{SC}$ and Emamectin benzoate $5 \mathrm{WG}$ found to be most effective.

\section{References}

Chatterjee, M.L., and Roy S. Bioefficacy of some insecticides against brinjal shoot and fruit borer (Leucinodes orbonalis Gunee) and effect of Novaluron on natural enemies of brinjal pests. Pestology. 28, 52-56.

Choudhary B. 1967. Brinjal vegetables. National book Trust, India, New Delhi, 50-58.

Gomez, K.A., and Gomez, A. A. 1984.Statistical Procedures for agricultural Research (2nd edn.), Wiley Interscience Pub. John Wiley and Sons, New York. 680 P.

Kalawate, A. and Dethe, M. D. 2006.Bioefficacy study of biorational insecticide on brinjal. J. Biopest., 5(1): 75-80.
Kumar, P., and Devappa V. Bioefficacy of emamectin benzoate $5 \% \quad \mathrm{SG}$ (Proclaim) against brinjal shoot and fruit borer. Pestology, 30, 17-19.

Mamun M. A. A, Islam K. S, Jahan M and Das G. 2014. Comparative potency of three insecticides against the infestation of brinjal shoot and fruit borer, Leucinodes orbonalis Guen. Scholars Academic Journal of Biopesticides. 2(6):364-369.

Mhaske, B.M., and Mote, U.N. 2005. Studies on evaluation of new insecticides against brinjal pest complex. Jourrnal of Maharashtra Agriculture University 30 (3): 303-306.

Regupathy, A., Palanisamy, S., Chandramohan, N. and Gunathilagaraj, K. 1997. A guide on crop pests. Sooriya Desk Top Publishers, Coimbatore, 264 P.

Sharma, A., and Sharma, P.C. 2010. Bioefficacy of insecticides against Leucinodes orbonalis on brinjal. Journal of Environmental Biology 31: 399-402.

Sinha, S.R. and Sharma, R. K. 2008. Pest management in brinjal through intercropping and newer molecules. In: Proceedings of the second Congrss on Insect Science, Punjab Agricultural University, Ludhianas, 21-22 February. Pp. 205-206.

Singh, M., and Sachan, S.K. 2015. Comparative efficacy of some biopesticides against shoot and fruit borer, Leucinodes orbonalis gunee in brinjal. Plant Archives. 15(2):805-808.

\section{How to cite this article:}

Gayathri, S., B. Geetha, T. Abdul Razak and Manivannan, M.I. 2019. Evaluation of Biorational Pesticides for Management of Shoot and Fruit Borer (Leucinodes orbonalis G.) in Brinjal. Int.J.Curr.Microbiol.App.Sci. 8(06): 3066-3070. doi: https://doi.org/10.20546/ijcmas.2019.806.365 